IKONOMIKA: Journal of Islamic Economics and Business

Volume 2, No I (2017)

ISSN: 2527-3434 (PRINT) - ISSN: 2527-5I43 (ONLINE)

Page : 93 - 102

\title{
Does Islamic Banking Contribute to Economic Growth and Industrial Development in Turkey?
}

\author{
Serhat Yüksel ${ }^{\mathrm{I}}$ and İsmail Canöz ${ }^{2}$ \\ İstanbul Medipol University ${ }^{\mathrm{I}}$, İstanbul Arel University ${ }^{2}$, \\ serhatyukse1@medipol.edu.tr', ismailcanoz@,arel.edu.tr ${ }^{1}$
}

\begin{abstract}
This paper aims to identify the effects of Islamic banking on economic growth and industrial development in Turkey. For this purpose, quarterly data for the periods between 2005 and 2016 were taken into the consideration. Additionally, VAR Granger causality analysis was used in this study. It was concluded that Islamic banks' loans do not have a significant effect on the improvement of economy and industry in Turkey. The main reason for this result is that Islamic banking has a very low percentage in Turkish banking sector. Thus, it can be said that Islamic banking in Turkey should be so developed that it can contribute to GDP growth and industrial development.
\end{abstract}

Keywords: Islamic Banking, Economic Growth, Industrial Development.

\begin{abstract}
Penelitian ini bertujuan untuk mengidentifikasi pengaruh perbankan syariah terhadap pertumbuhan ekonomi dan perkembangan industri di Turki. Data yang dipergunakan dalam penelitian ini adalah data kuartal dari tahun 2005 sampai dengan tahun 20I6. Teknik analisis yang dipergunakan ialah teknik kausalitas VAR Granger. Hasil penelitian menyimpulkan bahwa pembiayaan yang dilakukan oleh perbankan syariah tidak memiliki pengaruh yang signifikan terhadap perkembangan perekonomian dan industri di Turki. Alasan utama atas hasil ini ialah masih kecilnya persentase perbankan syariah pada sistem perbankan di Turki. Oleh karenanya dapat dikatakan bahwa perbankan syariah di Turki harus dikembangkan agar dapat berkontribusi pada pertumbuhan ekonomi dan perkembangan industri.
\end{abstract}

Kata Kunci: Perbankan Syariah, Pertumbuhan Ekonomi, Perkembangan Industry. 


\section{A. INTRODUCTION}

Islamic banking has become very popular especially in recent years. The main difference of Islamic banking system from traditional banking system is that there is no interest in this system. In other words, when people deposit their money to traditional banks, they have a guarantee to get previously determined amount of interest at the maturity. On the other hand, people do not feel certain in this respect when they deposit money to Islamic banks. They get the amount of profit sharing according to the profitability of these banks (Hassan and Bashir, 2003).

There are some reasons with respect to the appearance of Islamic banking system. First of all, religious reasons are very significant for this situation. Because interest is strongly prohibited in Islam, Muslim people need a banking system that does not have interest. In addition to the religious reasons, social reasons also play an important role in the appearance of Islamic banking system. It is believed that interest causes income inequality among people. Therefore, a new banking system without interest is needed to prevent this problem.

It is thought that Islamic banking system has many advantages in comparison with traditional banking system. Firstly, it increases liquidity in the market because Muslim people deposit money to the banks. Secondly, it plays a very significant role in decreasing the unemployment rate in the country since these banks employ new people. In addition to these factors, it also helps to increase production in the country by giving loans to the companies. Considering this situation, it can be said that Islamic banking system contributes to economic improvement in that country (Furqani and Mulyany, 2009).

The popularity of Islamic banking system has increased in Turkey especially in last 10 years. According to the data of Participation Banks Association of Turkey, the total assets of Islamic banks in Turkey increased from IO million TL in 2005 to 120 million TL in 20I5. In addition to this issue, total loans of these banks exceeded 77 million in 2015 whereas they were just 7 million TL in 2005. On the other hand, Islamic banks have only $5 \%$ share in total banking sector in Turkey. In summary, it can be said that Islamic banks play a very small role in Turkey, but their popularity has been increasing over the years.

In this study, it is aimed to evaluate the effects of Islamic banks on industrial production and economic growth in Turkey. Within this scope, quarterly data for the periods between 2005 and 2015 is used for this purpose. Additionally, VAR Granger causality analysis is considered for this situation. Although the relationship between Islamic banking and economic growth was analyzed many 
times, there is not a study which focuses on the relationship between Islamic banks and industrial development. Therefore, it is thought that this study will make a significant contribution to the literature.

\section{B. LITERATURE REVIEW}

Although Islamic banking is a subject that attracted the attention of many researchers, there are not many studies in which the relationship between Islamic banking and economic growth is explored. In addition to this, it is observed that there is not any study in the literature that focuses on the relationship between Islamic banking and private investment. Some of the similar studies in the literature are detailed on Table I.

Table I shows that there are lots of studies that underline the relationship between Islamic banking system and economic growth. Furqani and Mulyayn (2009) conducted a study to identify this relationship in Malaysia. They considered Johansen co-integration analysis to achieve this objective. They concluded that Islamic banking contributes to economic growth. Abduh and Omar (20I2), Tabash and Dhankar (20I4a) and Tabash and Dhankar (20I4c) also reached this conclusion with the help of the same method. In addition to those studies, Abduh and Chowdhury (2012), Yazdan and Dastan (2013) and Tabash and Dhankar (20I4b) emphasized the similar result with the help of Granger causality analysis. Furthermore, Kassim (2016) and Yazdan and Sadr (20I2) used ARDL test and determined that there is a strong relationship between Islamic finance and economic growth.

In spite of these studies, there are also some other studies which concluded that Islamic banking does not have an important effect on economic growth. Johnson (2013) carried out a study in which 345 different Islamic banks were taken into the consideration. From the results of regression analysis, it was determined that there is no relationship between Islamic banking system and economic growth. Lebdaoui and Wild (2016) also reached this result with the help of the same method. On the other hand, Tajgardoon et. al. (2013) concluded that Islamic bank does not contribute to economic growth in the long run by using a different methodology. Similarly, Wahab et. al. (2016) identified that Islamic banking does not affect economic growth in Pakistan. Hachicha and Amar (2015) emphasized this aspect for Malaysia. 
Table I

Similar Studies in the Literature

\begin{tabular}{|c|c|c|c|}
\hline Authors & Method & Scope & Result \\
\hline $\begin{array}{l}\text { Furqani } \\
\text { and } \\
\text { Mulyayn } \\
(2009)\end{array}$ & $\begin{array}{l}\text { Johansen } \\
\text { Cointegration } \\
\text { Analysis }\end{array}$ & Malaysia & $\begin{array}{l}\text { They conclude that there is a } \\
\text { relationship between GDP growth and } \\
\text { Islamic banking. }\end{array}$ \\
\hline $\begin{array}{l}\text { Abduh } \\
\text { and } \\
\text { Chowdhur } \\
\text { y (2012) }\end{array}$ & $\begin{array}{l}\text { Granger } \\
\text { Causality } \\
\text { Analysis }\end{array}$ & Bangladesh & $\begin{array}{l}\text { They reached a conclusion that there is } \\
\text { a positive and substantial relationship } \\
\text { between economic growth and Islamic } \\
\text { financial system. }\end{array}$ \\
\hline Abduh & Johansen & & They emphasized that there is a strong \\
\hline $\begin{array}{l}\text { and Omar } \\
(2012)\end{array}$ & $\begin{array}{l}\text { Cointegration } \\
\text { Analysis }\end{array}$ & Indonesia & $\begin{array}{l}\text { relationship between economic growth } \\
\text { and Islamic banking development. }\end{array}$ \\
\hline $\begin{array}{l}\text { Yazdan } \\
\text { and Sadr } \\
(2012)\end{array}$ & ARDL & $\begin{array}{l}\text { Iran and } \\
\text { Indonesia }\end{array}$ & $\begin{array}{l}\text { It was analyzed that there is a strong } \\
\text { relationship between Islamic finance } \\
\text { and economic growth. }\end{array}$ \\
\hline $\begin{array}{l}\text { Johnson } \\
(2013)\end{array}$ & Regression & $\begin{array}{l}345 \\
\text { Islamic } \\
\text { banks }\end{array}$ & $\begin{array}{l}\text { It was determined that there is no } \\
\text { relationship between Islamic banking } \\
\text { system and economic growth. }\end{array}$ \\
\hline $\begin{array}{l}\text { Sarwer et. } \\
\text { al. (20I3) }\end{array}$ & Survey & Pakistan & $\begin{array}{l}\text { They concluded that Islamic banking is } \\
\text { significantly and positively associated } \\
\text { with economic growth. }\end{array}$ \\
\hline $\begin{array}{l}\text { Tajgardoo } \\
\text { n et. al. } \\
\text { (2013) }\end{array}$ & $\begin{array}{l}\text { Granger } \\
\text { Causality } \\
\text { Analysis }\end{array}$ & $\begin{array}{l}\text { I2 Asian } \\
\text { countries }\end{array}$ & $\begin{array}{l}\text { It was identified that there is a } \\
\text { significant relationship between } \\
\text { economic growth and Islamic financial } \\
\text { system in the short run, but it is not } \\
\text { valid in the long run. }\end{array}$ \\
\hline $\begin{array}{l}\text { Yazdan } \\
\text { and } \\
\text { Dastan } \\
(2013)\end{array}$ & $\begin{array}{l}\text { Granger } \\
\text { Causality } \\
\text { Analysis }\end{array}$ & $\begin{array}{l}9 \text { Islamic } \\
\text { countries }\end{array}$ & $\begin{array}{l}\text { It was defined that Islamic banking } \\
\text { contributes to economic growth. }\end{array}$ \\
\hline $\begin{array}{l}\text { Yusof and } \\
\text { Bahlous } \\
\text { (2013) }\end{array}$ & $\begin{array}{l}\text { Pedroni } \\
\text { Cointegration } \\
\text { Test }\end{array}$ & $\begin{array}{l}\text { Malaysia, } \\
\text { Indonesia } \\
\text { and GCC } \\
\text { countries }\end{array}$ & $\begin{array}{l}\text { It was found that Islamic banking sector } \\
\text { contributes to economic growth both in } \\
\text { the short term and long term. }\end{array}$ \\
\hline Tabash & Johansen & Qatar & It was determined that there is a strong \\
\hline
\end{tabular}




\begin{tabular}{|c|c|c|c|}
\hline $\begin{array}{l}\text { and } \\
\text { Dhankar } \\
(20 I 4 \mathrm{a})\end{array}$ & $\begin{array}{l}\text { Cointegration } \\
\text { Analysis }\end{array}$ & & $\begin{array}{l}\text { relationship between economic growth } \\
\text { and Islamic banking. }\end{array}$ \\
\hline $\begin{array}{l}\text { Tabash } \\
\text { and } \\
\text { Dhankar } \\
(2014 b)\end{array}$ & $\begin{array}{l}\text { Granger } \\
\text { Causality } \\
\text { Analysis }\end{array}$ & $\begin{array}{l}\text { Qatar, } \\
\text { Bahrain, } \\
\text { UAE }\end{array}$ & $\begin{array}{l}\text { It was identified that there is a } \\
\text { significant relationship between Islamic } \\
\text { finance and economic growth. }\end{array}$ \\
\hline $\begin{array}{l}\text { Tabash } \\
\text { and } \\
\text { Dhankar } \\
(2014 c)\end{array}$ & $\begin{array}{l}\text { Johansen } \\
\text { Cointegration } \\
\text { Analysis }\end{array}$ & UAE & $\begin{array}{l}\text { They defined that there is a causality } \\
\text { relationship between Islamic banking } \\
\text { system and economic growth. }\end{array}$ \\
\hline $\begin{array}{l}\text { Gheeraert } \\
\text { and Weill } \\
(2015)\end{array}$ & $\begin{array}{l}\text { Stochastic } \\
\text { Frontier } \\
\text { Approach }\end{array}$ & $\begin{array}{l}70 \\
\text { countries }\end{array}$ & $\begin{array}{l}\text { It was concluded that there is a } \\
\text { relationship between Islamic finance } \\
\text { and economic growth. }\end{array}$ \\
\hline Hachicha & Johansen & & They reached a conclusion that Islamic \\
\hline $\begin{array}{l}\text { and Amar } \\
(2015)\end{array}$ & $\begin{array}{l}\text { Cointegration } \\
\text { Analysis }\end{array}$ & Malaysia & $\begin{array}{l}\text { financing does not affect economic } \\
\text { growth. }\end{array}$ \\
\hline $\begin{array}{l}\text { Abedifar } \\
\text { et. al. } \\
(2016)\end{array}$ & $\begin{array}{l}\text { Descriptive } \\
\text { Statistics }\end{array}$ & $\begin{array}{l}22 \text { Islamic } \\
\text { countries }\end{array}$ & $\begin{array}{l}\text { It was identified that there is a } \\
\text { relationship between market share of } \\
\text { Islamic banks and economic growth. } \\
\text { It was identified that Islamic banking }\end{array}$ \\
\hline $\begin{array}{l}\text { Kassim } \\
(2016)\end{array}$ & & Malaysia & $\begin{array}{l}\text { system contributes to economic } \\
\text { activities by financing investment } \\
\text { projects. }\end{array}$ \\
\hline $\begin{array}{l}\text { Lebdaoui } \\
\text { and Wild } \\
\text { (2016) }\end{array}$ & Regression & $\begin{array}{l}\text { Southeast } \\
\text { Asian } \\
\text { countries }\end{array}$ & $\begin{array}{l}\text { It was found that the relationship } \\
\text { between economic growth and Islamic } \\
\text { banking is significant in the long term } \\
\text { but it is not valid in the short term. }\end{array}$ \\
\hline $\begin{array}{l}\text { Tunay } \\
(2016)\end{array}$ & $\begin{array}{l}\text { Dumitrescu } \\
\text { and Hurlin } \\
\text { Causality Test }\end{array}$ & $\begin{array}{l}\text { I9 Islamic } \\
\text { countries }\end{array}$ & $\begin{array}{l}\text { It was determined that Islamic banks } \\
\text { play a critical role in economic growth. }\end{array}$ \\
\hline $\begin{array}{l}\text { Wahab et. } \\
\text { al. (2016) }\end{array}$ & $\begin{array}{c}\text { Engle Granger } \\
\text { Cointegration } \\
\text { Analysis }\end{array}$ & $\begin{array}{l}\text { Malaysia } \\
\text { and } \\
\text { Pakistan }\end{array}$ & $\begin{array}{l}\text { The relationship between Islamic } \\
\text { finance and economic growth is } \\
\text { significant in Malaysia but not } \\
\text { significant in Pakistan. }\end{array}$ \\
\hline
\end{tabular}




\section{METHOD}

While considering similar studies in the literature, it was determined that lots of studies evaluated the effect of Islamic banking on economic growth. Moreover, it was observed that different analysis methods, such as regression, Granger causality analysis and Johansen co-integration analysis were considered in those studies. Despite the abundance of studies in the area, it was identified that there is not a study which considers that the relationship between Islamic banking and industrial development. Therefore, it can be said that there is a need for a new study that analyses this concept.

In this study, growth rate of total loans amount of Islamic banks and industrial production index are taken into the consideration. Also, GDP growth rate is used in regards to economic improvement. Furthermore, quarterly data of these variables are analyzed and they are provided from the websites of Turkish Statistical Institute and Participation Banks Association of Turkey.

\section{RESULT AND DISCUSSION}

Granger causality analysis helps to analyze whether there is a causal relationship among the variables (Granger, 1969). Before starting this causality analysis, firstly, optimum lag interval is determined. In this process, Akaike Information Criteria and Shwartz Criteria are taken into the consideration and the results are given on Table 2 .

\section{Table 2}

Calculation of Appropriate Lag Length

\begin{tabular}{|c|c|c|c|c|c|c|}
\hline Lag & LogL & LR & FPE & AIC & SC & HQ \\
\hline 0 & -20.0508 & NA & 0.000655 & I.I8209 & $1.310057^{*}$ & I.228003 \\
\hline I & -4.60816 & 27.71749 & $0.00047 \mathrm{I}$ & $0.85 \mathrm{I} 70 \mathrm{I}$ & I.363566 & I.035353* \\
\hline 2 & 2.783632 & I2.130I2 & 0.000517 & $0.934 \mathrm{I} 73$ & I.829937 & I. 255565 \\
\hline 3 & I4.I7593 & I $6.94240^{* *}$ & $0.000468^{*}$ & $0.8 \mathrm{II} 49 \mathrm{I}^{*}$ & $2.09 \mathrm{II} 53$ & I. 270623 \\
\hline 4 & 22.26042 & I0.7793 I & 0.000513 & 0.85844 & 2.522002 & I.4553I2 \\
\hline 5 & 29.95408 & 9.074576 & $0.00059 \mathrm{I}$ & 0.925432 & 2.972892 & I.660043 \\
\hline 6 & 40.48897 & I0.80502 & $0.0006 \mathrm{I} 4$ & 0.846719 & 3.278079 & I.71907 \\
\hline 7 & 49.28627 & 7.669437 & $0.00074 \mathrm{I}$ & 0.857 II 5 & 3.672373 & I. 867205 \\
\hline 8 & $56.7766 \mathrm{I}$ & 5.37768 & 0.001043 & 0.934533 & 4.13369 & 2.082363 \\
\hline
\end{tabular}

* indicates lag order selected by the criterion 
LR: sequential modified LR test statistic (each test at 5\% level)

FPE: Final prediction error

AIC: Akaike information criterion

SC: Schwarz information criterion

HQ: Hannan-Quinn information criterion

Maximum lag interval was chosen as 8 for quarterly analysis

Table 2 shows that most of the " "x"symbols are located on the third lag. Therefore, in Granger causality analysis, optimum lag levels will be chosen as 3 .

\section{Table 3}

\section{VAR Granger Causality Analysis Results}

\begin{tabular}{ccc}
\hline Null Hypothesis & $\begin{array}{c}\text { Lag } \\
\text { Interval }\end{array}$ & $\mathrm{p}$ Value \\
\hline $\begin{array}{c}\text { Islamic banks' loans do not cause economic } \\
\text { growth. }\end{array}$ & 3 & 0.1689 \\
$\begin{array}{c}\text { Islamic banks' loans do not cause industrial } \\
\text { production. }\end{array}$ & 3 & 0.8427 \\
\hline
\end{tabular}

Table 3 gives information whether Islamic banking loans cause economic growth and industrial production. As it can be seen, probability values of both null hypothesis $(0.1689,0.8427)$ are higher than 0.05 , therefore, none of the null hypothesis can be rejected. Hence, it was concluded that there is not a causality relationship between Islamic bank loans and economic growth and industry production in Turkey. Johnson (2013), Lebdaoui and Wild (2016), Tajgardoon et. al. (20I3), Wahab et. al. (20I6) and Hachicha and Amar (20I5) reached the similar conclusions in their studies. The main reason behind this situation is that the percentage levels of Islamic banks in Turkish banking sector is very low. Because of this situation, it does not contribute to economic and industrial improvement.

\section{E. CONCLUSION}

The popularity of Islamic banking is increasing almost all around the world. Many different factors are effective in the appearance of this banking system. For example, because Muslim people are sensitive to Islamic rules, there is a need for a banking system that does not have interest. Moreover, since many researchers believe that interest increases income inequality among people, a new banking system without interest is needed. Turkey is a Muslim country where some Islamic 
banks operate. Although their percentage is very low in comparison with traditional banks, their popularity has gone up significantly especially in last IO years.

The main purpose of this study is to evaluate whether Islamic banking system contributes to industrial production and economic growth in Turkey. Within this scope, quarterly data for the periods between 2005 and 2016 were taken into the consideration. Furthermore, VAR Granger causality analysis was used in order to reach this objective. Optimum lag interval is defined as 3 by considering Akaike Information Criteria and Shwartz Criteria.

From the results of the causality analysis, it was identified that there is not a causality relationship between Islamic bank loans and economic growth and industry production in Turkey. In other words, Islamic banking sector in Turkey does not have a contributing factor to the economic and industrial improvement. This is mainly because of the low percentage of Islamic banks in Turkey when compared with traditional banks. Hence, it will be better to carry out this analysis again when the size of Islamic banks in Turkey has increased. Although a lot of studies have analyzed the relationship between Islamic banks and economic development, there is not a study in the literature that focuses on the effect of Islamic banks on industrial production. Thus, this study makes an important contribution to the literature by considering this factor in the analysis. Nevertheless, a new study that focuses on high number of countries with a longer period of time will be more beneficial.

\section{REFERENCES}

Abedifar, P., Hasan, I., \& Tarazi, A. (2016). Finance-growth nexus and dualbanking systems: Relative importance of Islamic banks. Journal of Economic Behavior \& Organization. I32 (Suplement): I98-2I5.

Abduh, M., \& Chowdhury, N. T. (2012). Does Islamic banking matter for economic growth in Bangladesh. Journal of Islamic Economics, Banking and Finance, 8(3): I04-II3.

Abduh, M. \& Omar, M. A. (2012). Islamic Banking and Economic Growth: The Indonesian Experience. International Journal of Islamic and Middle Eastern Finance and Management. 5(I): 35-47. 
Farahani, Y. G., \& Sadr, S. M. H. (20I2). Analysis of Islamic bank's financing and economic growth: Case study Iran and Indonesia. Journal of Economic Cooperation \& Development, 33(4), I-24.

Furqani, H., \& Mulyany, R. (2009). Islamic banking and economic growth: Empirical evidence from Malaysia. Journal of Economic Cooperation and Development, $30(2): 59-74$.

Gheeraert, L., \& Weill, L. (2015). Does Islamic banking development favor macroeconomic efficiency? Evidence on the Islamic finance-growth nexus. Economic Modelling, 47: 32-39.

Granger, C. W. (I969). Investigating causal relations by econometric models and cross-spectral methods, Econometrica: Journal of the Econometric Society. 37 (3): 424-438.

Farahani, Y.G., \& Dastan, M. (2013). Analysis of Islamic banks' financing and economic growth: a panel cointegration approach. International Journal of Islamic and Middle Eastern Finance and Management. 6(2): I56-I72.

Hachicha, N. \& Ben Amar, A. (2015). Does Islamic bank financing contribute to economic growth? The Malaysian case. International Journal of Islamic and Middle Eastern Finance and Management, 8(3): 349-368.

Hassan, M. K. \& Bashir, A. H. M. (2003). Determinants of Islamic banking profitability. In IOth ERF annual conference, Morocco (pp. I6-I8).

Johnson, K. (2013). The Role of Islamic Banking in Economic Growth. Claremnont Colleges, CMC Senior Theses Papers, No: 642, April.

Kassim, S. (2016). Islamic finance and economic growth: The Malaysian experience. Global Finance Journal, 30. 66-76.

Lebdaoui, H., \& Wild, J. (2016). Islamic banking presence and economic growth in Southeast Asia. International Journal of Islamic and Middle Eastern Finance and Management, $9(4): 55$ I-569

Mohd. Yusof, R., \& Bahlous, M. (2013). Islamic banking and economic growth in GCC \& East Asia countries: A panel cointegration analysis. Journal of Islamic Accounting and Business Research, 4(2), I5I-I72.

Sarwer, M.S., Ramzan, M., \& Waqar Ahmad, M. (2013). Does islamic banking system contributes to economy development. Global Journal of Management and Business Research, I3(2): 60-68. 
Does Islamic Banking Contribute to Economic Growth and Industrial Development in Turkey? (Serhat Yüksel ${ }^{1}$ and İsmail Canöz ${ }^{2}$ )

Tabash, M. I., \& Dhankar, R. S. (20I4a). Islamic Banking and Economic Growth: An Empirical Evidence from Qatar. Journal Of Applied Economics And Business, 2(I), 5I-67.

Tabash, M. I., \& Dhankar, R. S. (20I4b). The flow of Islamic finance and economic growth: An empirical evidence of Middle East. Journal of Finance and Accounting, 2(I), I I-I9.

Tabash, M. I., \& Dhankar, R. S. (20I4c). Islamic Finance and Economic Growth: An Empirical Evidence from United Arab Emirates (UAE). Journal of Emerging Issues in Economics, Finance and Banking, 3(2), I069-I085.

Tunay, K. B. (2016). Islami Bankacilik ile Ekonomik Büyüme Arasinda Nedensellik Iliskileri/Causality Relations Between Islamic Banking and Economic Growth. Yonetim ve Ekonomi, 23(2), 485.

Wahab, M., Mufti, O., \& Murad, M. S. (2016). The Study of Co-integration and Causal Link between Islamic Bank Financing and Economic Growth. Abasyn University Journal of Social Sciences. 9. I34-I46. 